I Programa de Pós-Graduação em História Social (PPGHIS),

Instituto de História, Universidade Federal

do Rio de Janeiro (UFRJ), Brasil

andreadaher@gmail.com

Andrea Daher'

\title{
NATHAN WACHTEL: HISTÓRIA E ANTROPOLOGIA DE UMA AMÉRICA "SUBTERRÂNEA" *
}

À memória de John Monteiro

Em I992, o Collège de France recebia Nathan Wachtel como titular da "Cátedra de História e antropologia das sociedades meso e sul-americanas". Nada mais adequado do que um título como este, que abriga plenamente o seu trabalho de etno-história, inaugurado em I97 I com La vision des vaincus [A visão dos vencidos]. Neste livro, tornado clássico, é o ponto de vista dos índios do Peru, confrontados aos conquistadores espanhóis, que dá inteligibilidade à sua própria história.

Foi preciso quase vinte anos de pesquisas para que Wachtel recolhesse, a seguir, na Bolívia, os traços identitários de populações que atravessaram quatro séculos de experiências violentas de conquista. Remontar do presente em que se encontram esses traços ao passado mais distante de que são resíduos é uma ambição largamente cumprida em Le retour des ancêtres [O Retorno dos ancestrais], de I990.

No começo da década seguinte, essa mesma experiência intelectual se volta para o que Wachtel chamaria de "ciclo de estudos marranos", materializado em três livros. La foi du souvenir [A fé na lembrança], de 200I, segue a máxima benjaminiana de que "nada do que alguma vez aconteceu está perdido para a história", estampada em epígrafe, desde a primeira página do livro. $\mathrm{O}$ que parece "perdido para a história" pôde, sem dúvida, ser encontrado entre memória e esquecimento, nas trajetórias de marranos ibéricos refugiados na América. Fiéis às escondidas, suas práticas e suas "formas de pensamento" fo- 
ram, assim, trazidas à tona e significadas no interior de uma "condição de vida marrana". Em La logique des bûchers [A lógica das fogueiras], de 2009, Wachtel toma os dispositivos inquisitoriais dos tribunais ibéricos que perscrutam essa "condição marrana" como práticas racionais baseadas na gestão lógica da prova, cujas formas são relacionadas - no interior de uma anacronia histórica controlada - aos sistemas totalitários do século XX. A trilogia se completa, por fim, em 20I I, com Mémoires marranes [Memórias marranas], que reúne relatos de histórias vividas no Nordeste do Brasil, neste século XXI. Um percurso de mais de dez anos de pesquisa de campo resultou, assim, na construção de uma memória marrana brasileira, sempre dilacerada entre duas vontades - de fidelidade e de apagamento - e entre duas posturas - de perseverança e de recusa -, mas que faz ecoar, em todo caso, as mesmas vontades e posturas de um passado distante e, de certo modo, recalcado.

No Rio de Janeiro, Nathan Wachtel nos falou dessa sua singular experiência de trabalho, em que o relato dos vivos se une à letra dos mortos, índios ou marranos, como história de uma América "subterrânea", soterrada nas conquistas do passado, porém viva em vestígios de memórias no nosso presente.

Andrea Daher. É reconhecível na sua obra, desde La vision des vaincus até o último livro da sua trilogia sobre o marranismo, Mémoires marranes, uma tensão permanente entre passado e presente, que se desdobra numa perspectiva que é, ao mesmo tempo, histórica e antropológica. Em seu segundo livro, Le Retour des ancêtres, surge a seguinte explicação: "Se a parte etnológica precede aqui a parte histórica, não é, portanto, para projetar esquematicamente o presente no passado". Esse é, aliás, um livro que parte de um trabalho etnográfico na Bolívia e, através de uma "história regressiva" feita a partir de pesquisa em arquivos, remonta até o século XVI. É uma maneira muito interessante de relacionar presente e passado, definida em seus próprios termos: “Trata-se, combinando problemáticas, técnicas, das duas disciplinas [história e etnografia], na base de um material duplamente composto, de definir o modelo ao qual se conforma a sociedade chipaya, de estudar a sua gênese e de seguir a sua evolução através dos tempos da história" (ver Wachtel, I990: 9, tradução nossa). Nesse sentido, pergunto: como se poderia definir essa tensão entre passado e presente na sua obra? Como se fundamenta essa necessidade de compreender o presente, de partir dele ou, nesse caminho regressivo ao passado, de se chegar numa questão levantada no presente? E a pergunta se desdobra, talvez, no sentido de uma indagação de caráter mais ético-político: existe algum traço de dever de memória nessa relação, na sua obra, entre presente e passado?

Nathan Wachtel. Nos anos I96o, quando comecei a buscar um tema de pesquisa para a minha tese, no contexto geral da descolonização, vivíamos algo que foi mais que um episódio: foi o drama, para a França, da guerra com a Argélia e a emergência do que na época se chamava "Terceiro Mundo". De minha par- 
te, tive vontade de sair do estudo da história da França e de trabalhar sobre esse "vasto mundo", que incluía nada menos que a África e a América Latina. A possibilidade de estudar América Latina surgiu, mais precisamente, em conversa com Ruggiero Romano, historiador ligado aos Annales. E por que a América Latina? Por questão de fontes. As fontes da administração espanhola ou portuguesa são, de fato, muito mais ricas que as da África, onde a documentação é não apenas mais pobre, mas também nem tão antiga. E por que o Peru, a Bolívia e os Andes, antes que o México? Porque México estava um pouco mais estudado que os Andes. Na conversa como Romano surgiu a ideia de estudar a conquista espanhola do ponto de vista dos índios, do ponto de vista dos vencidos. E nessa época eu não havia ainda lido Walter Benjamin e suas famosas teses sobre a história, em que diz, de maneira tão obscura quanto sugestiva, que não se há de continuar a fazer uma história erudita, acadêmica, como história dos vencedores, dos dominantes. Só descobri Benjamin mais tarde. Mas a ideia de estudar a visão dos vencidos, suponho, tinha algo a ver com minha experiência da Guerra, das perseguições e das vítimas. Eu não precisava ter lido Benjamin para ter interesse nas vítimas e nos vencidos.

Mas ninguém tem a obrigação de fazer como eu fiz: trabalho de pesquisa histórica nos arquivos e trabalho de pesquisa etnográfica em campo. Não há nenhuma obrigação nesse sentido, pois isso depende do tema, depende das possibilidades de fazer trabalho de campo etc. No caso do estudo que resultou no livro Le retour des ancêtres, havia uma vasta documentação conservada nos arquivos de Sevilla, de Lima, de Sucre - os arquivos de Sucre são uma maravilha. Escolhi os índios Urus porque sabia, pela literatura produzida por meus predecessores, que havia um enclave de índios que não eram Aymaras, dominantes na Bolívia, mas Urus, dominados por seus vizinhos Aymaras. Meu interesse se voltou, então, dessa vez, para o estudo histórico e antropológico "dos vencidos dos vencidos". Era uma maneira de aprofundar a questão. Mas, por outro lado, a propósito da tensão passado-presente e da história regressiva, como disse, os Annales que eu havia conhecido na minha formação não eram uma escola, nem mesmo uma doutrina, mas um "espírito" que tratei de assumir. Foi Robert Mandrou que me recomendou a leitura e me fez descobrir Marc Bloch. Comecei pelo seu maravilhoso livro sobre a derrota da França em I940, L'étrange défaite (I946) (lembremos que Marc Bloch é um historiador medievalista, mas esse é um dos melhores estudos sobre a sociedade francesa dos anos I 920 e I930). O método regressivo é recomendado e praticado por Bloch quando, por exemplo, em seu livro sobre a história rural da França (I93I) - em que pese a formação geográfica que tinham, então, os historiadores franceses -, ele estuda as paisagens e a cartografia do século XX de modo regressivo. A propósito do vínculo entre passado e presente, Marc Bloch afirma, em sua Apologia da história. O ofício do historiador (2002), que a história é uma ciência que consiste em unir no tempo o estudo dos mortos com o estudo dos vivos. 
Minha formação é, portanto, uma formação de historiador, marcada porém pela obra e pelos ensinamentos de Claude Lévi-Strauss, de quem fui aluno. A leitura de Tristes trópicos (200I), em particular, me trouxe o interesse de juntar história e antropologia. No que diz respeito à minha experiência de trabalho, ao trabalho de campo, creio hoje que tenha sido algo um tanto ingênuo e romântico. Talvez fosse uma ilusão, mas havia algo comovente em fazer essa experiência de trabalho de campo com os descendentes do povo que eu encontrava, três séculos antes, na documentação conservada nos arquivos. E, reciprocamente, o trabalho nos arquivos ganhava outra dimensão a partir do momento em que comecei a conhecer os descendentes daquele povo do passado no meu próprio presente. Por que essa ideia de reunir o estudo dos vivos e o estudo dos mortos? Havia a recomendação de Marc Bloch e havia também, nessa pesquisa, à maneira que descreve Walter Benjamin, alguns momentos privilegiados em que o passado irrompia no presente. Sentimos o passado vivendo no presente. E é assim que temos experiências excepcionais.

Uma dessas experiências, que vivi de uma maneira realmente muito comovente, foi narrada no livro Le retour des ancêtres. Então, se me permitem, vou repetir essa história, que lhe dá o título. Por que "O retorno dos ancestrais"? O que significa isso? Refiro-me a uma passagem do livro, que narro agora, indicando, antes de tudo, o contexto: os Urus-Chipayas são um enclave de duas mil pessoas na Bolívia, num deserto de sal, na encosta de um lago salgado, semidesértico. Mas os Chipayas conseguiram um pedaço de território. Metade desse território é totalmente desértica, e a outra metade é irrigada, onde se cultiva quinua (e nada mais que quinua), junto à criação de algumas poucas cabeças de gado, de lhamas e de cordeiros. Em meados do século XVI, quando chegaram os espanhóis, os Urus representavam $25 \%$ da população indígena. E o que aconteceu? Hoje em dia, os Chipayas não representam sequer 0, I\%: são dois mil índios, não mais que isso. Não são os únicos sobreviventes dos Urus: restam ainda alguns, ao longo do Desaguadero que une o Lago Titicaca com o Lago Poopó. Mas esses Urus continuam a ser, como sempre foram, pescadores, caçadores de aves aquáticas, e não possuem terras. Continuam dominados por seus dominantes Aymaras. Os Chipayas são os únicos que sobrevivem como comunidade, graças ao seu território, mais precisamente, embora esse território seja paupérrimo. Conservam seus costumes próprios, têm um sentimento muito agudo de identidade e conservam também o seu idioma. São, aliás, trilíngues: têm o seu idioma próprio, que chamam puquina (há um debate entre os linguistas sobre se esse é o verdadeiro puquina ou não, mas, de todo modo, é dessa forma que o denominam); falam também o aymara; e, como há uma escola no povoado desde I940, quase todos, salvo os mais velhos, falam espanhol. Pude fazer minha pesquisa de campo em castelhano e, embora não tenha aprendido o puquina, tive de aprender algumas noções de sua visão de mundo, de seus ritos etc. Se conto aqui tudo isso é porque encontrei também, no Desa- 
guadero, outros Urus que são mais misturados com os Aymaras, que não possuem terras e que, à época, já não falavam puquina, e sim aymara. E quando contei aos meus informantes em Chipaya que havia outros Urus, eles então me disseram algo como: "Sim, já ouvimos dizer que temos irmãos". Não sei se isso é recomendado pela deontologia científica, no sentido de que não se deve intervir no objeto estudado - mas intervimos sempre, é inevitável. Nossa simples presença já é uma intervenção, isso há de ser levado em conta. Então, continuei intervindo e propus a dois de meus informantes que me acompanhassem numa viagem de trezentos quilômetros (isso significava voltar a Oruro, uma viagem de três dias), para visitar os irmãos Urus do Desaguadero. Eles, com entusiasmo, fizeram a viagem. Chegamos à aldeia dos Muratos, que é o nome do grupo do Lago do Desaguadero, onde os Chipayas foram acolhidos com grande emoção, em verdadeira confraternização. Ficamos dois ou três dias, não mais que isso, porque não tínhamos tempo e tampouco queríamos abusar da gentileza dos $\mathrm{Mu}$ ratos, que são ainda mais pobres que os Chipayas. Uns pareciam com os outros, mas os Chipayas, como diziam os Muratos em seu espanhol, eram ricatus, ou seja, riquíssimos, pois possuíam terras. E, mais ainda, os Chipayas haviam conservado o idioma dos antepassados. Os Muratos, como já disse, esqueceram a sua língua, salvo uma senhora que sabia alguma coisa.

A.D. E falavam, então, castelhano?

N.W. Aymara e castelhano, sim. Os outros falavam puquina, aymara e castelhano, e entre eles se comunicaram em aymara. De que falavam, todo tempo, durante o encontro? Precisamente do idioma. Os Muratos passaram esses dois ou três dias perguntando: "E como se diz isso em puquina?" Eles haviam guardado alguns termos da língua puquina relacionados ao parentesco, ou termos para a fauna, para os peixes e aves, o que se explica por seguirem sendo pescadores. Eles mesmos se designam como "homens d'água".

Mas o momento excepcional se sucedeu ao final do encontro. No momento da despedida, homens e mulheres se posicionaram formando um círculo, com os Chipayas ao centro, e o chefe, a autoridade dos Muratos, pediu que falassem em seu idioma, no idioma dos ancestrais. Os visitantes Chipayas falaram puquina, o que para eles era natural, como falam todos os dias, em sua aldeia. Nesse momento aconteceu algo realmente comovente - eu estava a ponto de chorar. Todos os Muratos, homens e mulheres, tiraram o chapéu, inclinaram a cabeça e ouviram a conversa entre os Chipayas como se fosse uma oração, de maneira religiosa. Isso era, para eles, como o retorno dos ancestrais. Era, então, o passado que voltava a viver no presente. Esse foi um momento benjaminiano. Os Chipayas falaram durante um momento e, quando terminaram, os Muratos, que haviam escutado tirando o chapéu, se posicionaram em fila, e homens e mulheres, um atrás do outro, abraçaram cada um dos Chipayas para agradecê-los por sua presença e por de serem, dessa maneira, como uma encarnação de seus ancestrais. 
A.D. Que sentidos de história e de antropologia resultaram, então, dessa experiência etnográfica singular?

N.W. Concebo Le retour des ancêtres como o trabalho em que tratei de juntar, da maneira mais completa possível, o método histórico de trabalho de arquivo e o método etnográfico de trabalho de campo, porque o tema se prestava a isso. Mas, mais em detalhe, como se complementam praticamente etnografia e história? Vou tratar de explicá-lo. Concebi o livro também, modestamente, como dizíamos nessa época, como um livro de "história total". Em que medida "total"? Na medida em que tratei de estudar como se articulavam o substrato demográfico, primeiro, e o econômico, a seguir, segundo o modelo dos Annales. Então, como se articulavam economia, sociedade e cultura? Comecei, para seguir a história regressiva, com o trabalho etnográfico, que tem como meta chegar a um modelo que pode ser um modelo antropológico, porque a partir do trabalho de campo se estuda como funciona a organização da vida econômica, a organização do espaço, a organização da sociedade e de seus distintos grupos, da vida política, digamos, na relação com as autoridades (os "alcaldes", o "corregidor", que são títulos espanhóis). E, acima disso, estavam a vida religiosa e a síntese do que chamei "sistema pagão-cristão", porque do ponto de vista religioso esses índios têm suas festas, seus cultos das divindades (a Pachamama, os Mallkus etc.) associados intimamente com os santos e o cristianismo. Então, a partir do trabalho de campo pude reconstituir esse modelo que organiza o conjunto da sociedade uru-chipaya - "modelo" é uma palavra diante da qual não devemos nos assustar. Em que consiste isso? Consiste em reconstituir o sistema de pensamento, de classificação. Nisso também sigo Lévi-Strauss. Mas é o sistema dos informantes, não o meu, embora traduzido em nosso vocabulário científico. E então, de que se trata? Trata-se de uma organização que encontramos em todo o mundo andino, até o Peru, excluindo o Equador: o sistema dualista. O sistema de pensamento dualista significa o jogo de categorias tais como acima-abaixo, esquerda-direita, masculino-feminino. A partir desse jogo de categorias de oposição e de complementaridade se organiza o espaço, as duas metades da aldeia com as quatro esquinas e os quatro bairros. Esse modelo dualista e quadripartite organiza - embora agora não possa entrar em detalhes - tanto a vida econômica quanto a vida cultural religiosa, como um sistema de peças que se complementam (deuses andinos e entidades cristãs). Esse sistema, finalmente, não é tão original, na medida em que o sistema dualista que encontramos em todos os Andes bolivianos e peruanos é o mesmo sistema que os Urus-Chipayas adotaram dos Aymaras. Mas a pergunta é: como explicar esse sentimento distinto de identidade entre eles? Eles possuem uma identidade distinta dos Aymaras, com um sistema de organização social e de pensamento que é simplesmente o mesmo. Como explicar esse paradoxo de uma organização muito parecida com a organização aymara, enquanto os Urus não tinham esse sistema dualista? 
Não posso expor aqui as 700 páginas do livro. Mas, para tratar de responder ao problema que procede do estudo etnográfico, o caminho que tratei de seguir para buscar explicações foi a pesquisa histórica. Esse modelo existia no presente etnográfico dos anos I970, e ainda nos I980. Como se constituiu? A partir de quando existe? Como evoluiu? E podemos dar uma explicação his tórica? O problema é antropológico e minha explicação, a explicação que tratei de dar à pergunta do problema antropológico, é uma explicação histórica. Qual é essa explicação histórica? A grande maioria da população Uru se reduziu de $25 \%$ a $5 \%$, já na metade do século XVII. O que aconteceu? No século XVII, não houve matança dos Urus mais que dos outros indígenas. Tampouco havia razão para que as doenças, as epidemias tivessem mais impacto sobre uns que sobre outros. O que aconteceu? Foi um fenômeno que começou a se produzir já no tempo dos Incas: a documentação conservada nos arquivos apresenta alguns elementos que provam que o processo de sedentarização dos Urus, "homens d'água", havia começado já na época dos Incas. Não entro em detalhes agora em relação a todo o sistema de trabalho obrigatório, mas lembro que os Urus tinham o privilégio de serem trabalhadores de obrigação em relação aos Incas e foi dessa forma que puderam começar a ter algumas parcelas de terra. O fenômeno se acentuou durante a segunda metade do século XVI e todo o século XVII. Cabia saber as razões. Então, para essa história total tive de seguir os métodos clássicos da história, à época, sobretudo os métodos estabelecidos por Ernest Labrousse baseados, fundamentalmente, em curvas de preços e em curvas demográficas (muito bem ilustrados pelo trabalho de Pierre Goubert). Que relação tem tudo isso com essa aldeia de Chipayas? Como consequência das epidemias, que acabo de mencionar - sobretudo as de varíola que, como sabemos, foram desastrosas -, na segunda metade do século XVI pode-se estimar que $80 \%$ ou $90 \%$ da população indígena desapareceu. O que aconteceu então? Durante o século XVII havia pouca gente e muito espaço, e os Urus puderam, com isso, se sedentarizar facilmente. Não se sedentarizaram nas melhores terras, claro, mas nas terras mais inóspitas. Os Aymaras, que também foram diminuindo, não puderam impedir que se estabelecessem em algumas terras. E o que aconteceu? Estes Urus que se sedentarizaram ao mesmo tempo adotaram os costumes e os valores da cultura dominante. A cultura dominante não era a espanhola, mas, para eles, a aymara: eles se "aymarizaram". E há provas disso na documentação da administração espanhola, em que se pode ler que em tal aldeia os Urus "se confundiram com os demais na população". Uma vez "confundidos", "misturados" aos demais e já não podiam ser reconhecidos enquanto Urus: já eram Aymaras. E, também, estudando em detalhe as distintas categorias de taxas, de impostos, era possível ver a distinção que então se fazia entre Urus e Aymaras. Como se pode concluir à leitura das listas de taxas, os primeiro pagavam menos taxas porque eram mais pobres. Porém, entre o século XVII e o século XVIII, muitos passaram da categoria de Uru à categoria de 
Aymara, passando com isso a pagar mais. Num sistema paradoxal como esse, desde o século XVI, portanto, há Urus que pedem para ser classificados como Aymaras, porque isso era mais prestigioso, embora passassem a pagar mais taxas. Assim, a maioria dos Urus se "aymarizou", salvo um reduto, é claro, constituído por aqueles que não conseguiram a posse de terras. E os Chipayas formavam, justamente, a parte dos Urus que continuava sendo uru - ou seja, gente considerada bárbara, selvagem, detentora de outro idioma, de outros costumes etc. O que aconteceu com os Chipayas é que eles se tornaram a exceção que confirmava os demais, visto que acabaram por conseguir seu pedaço de terra na segunda metade do século XVIII. Mas as curvas demográficas e as curvas de preços indicam que, sobretudo nessa segunda metade do século XVIII, já havia uma mudança de conjuntura, ou seja, que a população se recuperou e cresceu. Durante o século XVII e começo do XVIII, digamos, tinha-se terra abundante e população rara. Pouco mais de meio século depois, tinha-se o contrário: a terra já era mais rara e a população mais numerosa. Os Chipayas tiveram de combater, de lutar, de fazer guerra, física e juridicamente, contra seus vizinhos. $E$, não sei por que milagre, eles conquistaram alguns direitos junto aos administradores espanhóis que reconheceram os limites de suas terras desérticas. Não sei se essa é uma explicação total, mas me parece uma explicação que já permite entender como eles puderam adotar o modelo de organização aymara, mas conservaram sua identidade de Urus, porque tiveram de lutar contra seus vizinhos. Hoje em dia, eles narram essas histórias como feitos heroicos de seus ancestrais, e o conflito segue assim até hoje: esses conflitos de conquista e de defesa de terras fazem com que esse passado siga presente. Ao que me parece, isso permite entender algo da identidade chipaya, que é o fio condutor desse livro, e será o fio condutor da trilogia seguinte: como a memória é o componente fundamental da identidade.

A.D. Esse mesmo fio condutor o levou, sem dúvida, a adotar recorrentemente o procedimento de buscar no trabalho de campo aquilo que é passível de ser encontrado nos arquivos, e vice-versa. Em Mémoires marranes, mais uma vez, o trabalho consiste em buscar hoje, no Nordeste do Brasil, resíduos de representações marranas. Esse é um trabalho etnológico, por excelência.

N.W. Concordo totalmente.

A.D. Sobre esse trabalho, gostaria de indagar, primeiro, quanto à ideia de um "marranismo indígena", que aparece vagamente em alguns de seus trabalhos. Como se sabe, é perceptível, sobretudo a partir da segunda metade do século XVI, uma continuidade entre a luta contra a heresia na Europa e a "conquista das almas" na América, do ponto de vista, digamos, contrarreformado. Nesse sentido, gostaria de projetar a reflexão para os objetos de seus estudos andinos e da sua trilogia marrana: há analogias observáveis entre esses marranos, cristãos novos, 
judeus (categorias essas que merecem, é claro, ser nuançadas) e índios da América, como os Urus-Chipayas, do ponto de vista do historiador dessas culturas? N.W. A resposta mais simples e, para não entrar agora em outros matizes, é que não há relação direta, não se pode ter uma relação direta. Mas há analogia, e não somente retórica. Falo, sim, entre aspas, de um "marranismo indígena". Durante uma época, antes que se constituísse precisamente esse sistema sincrético pagão-cristão, houve um momento em que os dois sistemas de ritos estavam justapostos, digamos, durante a segunda metade do século XVI. E quando se constitui esse modelo de sincretismo pagão-cristão? Não há uma data exata, evidentemente, mas eu diria que foi ao longo do século XVII. E repito, durante a segunda metade do século XVI e começo do XVII, há relatos de que os índios praticavam, no exterior, ritos cristãos de maneira bastante dócil, como recomendavam os padres; e que, clandestinamente, no interior, praticavam seus ritos aos Mallkus, à Pachamama. Há casos, por exemplo, de descoberta, debaixo do altar da igreja, de uma pedra que representa o espírito de tal ser ou de tal ídolo. Foi isso que considerei como um tipo de "marranismo". Ou seja, nessa justaposição entre o exterior dissimulado e o interior voltado para a fé verdadeira, podemos estabelecer uma analogia com o marranismo.

Agora darei um matiz a mais à resposta (que não indico tampouco no livro Memórias marranas, em que faço rapidamente uma alusão apenas ao que direi). Antes de fazer a pesquisa no Nordeste do Brasil, eu havia trabalhado nos arquivos do México (que são riquíssimos em documentação inquisitorial). Eu havia ouvido falar, então, de uma aldeia, localizada a uns roo quilômetros a nordeste da Cidade do México, próximo da pequena cidade mineira de Pachuca: chama-se Venta Prieta (hoje subúrbio de Pachuca). Foi lá que ouvi histórias e li artigos de jornalistas - e também de um ou dois historiadores - sobre os "índios judeus". Também na documentação oficial da comunidade judia do México, fala-se dos "aborígenes judeus" de Venta Prieta. Então, fiquei muito interessado em encontrar essa gente. Na realidade, eles nada têm de índio: são como todos os mexicanos, ou seja, alguns deles são mais ou menos escuros, outros de cor bem branca e até loiros. Há de todo tipo, mas eles se consideram todos descendentes de cristãos-novos. Comecei a trabalhar, a pesquisar sobre eles, mas não continuei, e isso por duas razões: porque, como bons marranos, não eram muito abertos - e tinham toda a razão de não o serem -, sobretudo porque estavam ressentidos em relação aos artigos que então se publicavam sobre eles. Para explicar que a minha intenção não era a de um jornalista, levei um bom tempo. E talvez eu tenha chegado tarde demais, pois me disseram que haviam regressado ao judaísmo nos anos I920 e I930. Quanto às lembranças do tempo em que praticavam costumes clandestinos, sua memória já não era tão rica.

Além disso, os habitantes de Venta Prieta recusam totalmente serem considerados como índios ou descendentes de índios e tampouco duvidam que descendem de cristãos-novos. Observei, ainda, que a profundidade de sua me- 
mória genealógica não era tão grande, pois não ia mais que ao começo do século XX, ou ao final do século XIX. E quando descobri que, aqui no Brasil, a memória genealógica daqueles cujos relatos de vida apresento em meu livro remonta facilmente, em muitos casos, ao começo do século XVIII e até finais do século XVII, fiquei impressionado. Por isso continuei a pesquisa aqui, embora os dados recolhidos paralelamente nos arquivos históricos sejam fragmentários. Ao estudarmos a memória, não podemos deixar de levar em conta o esquecimento: o que está presente na memória é o que sobrevive ao esquecimento. De todo modo, os relatos de vida e a descrição dos costumes eram um material muito mais rico, e isso fez com que eu continuasse a pesquisa no Nordeste do Brasil.

Dito isto, não há relação direta entre índios e cristãos-novos marranos. O fio condutor que relaciona as duas pesquisas é a problemática: a problemática da memória e da identidade. A memória como fundamento da identidade é o fio condutor do segundo ciclo de pesquisas que realizei.

A.D. Nesse trabalho monumental realizado tanto em seus primeiros livros sobre os ameríndios quanto na trilogia mais recente sobre os marranos são mobilizadas categorias de largo uso, tal como a de "sincretismo cultural", a que se referiu há pouco. Noções como esta estão muito marcadas por uma concepção de aculturação, tal como aparece no artigo de sua autoria publicado, em meados dos anos I970, no volume dirigido por Pierre Nora e Jacques Le Goff, História: novos problemas (1976). A seguir, essa noção assumiu uma função central na definição do movimento recíproco de aculturação que caracteriza, por exemplo, as relações entre cultura letrada e cultura popular. Ela deveria se tornar mais apta a dar conta do caráter permeável das "culturas", no sentido de que uma cultura colonizadora ou dominante pode ser permeada pela cultura dominada, fazendo com que sejam produzidos novos objetos, novas representações e, enfim, novas práticas sociais. Qual o papel desempenhado por noções como essas, de "aculturação" ou de "sincretismo", na perspectiva dessa dinâmica de permeabilidades culturais, no seu trabalho?

N.W. Sim. Há palavras e noções que têm sua moda. Na época em que escrevi o artigo sobre "aculturação", na coletânea de Nora e Le Goff, a questão estava na moda, agora já menos. Mas penso que essas noções vagas de aculturação, de sincretismo ou de mestiçagem sempre têm seu valor, claro, mas com a condição de que precisemos como os componentes que vêm de culturas distintas se combinam (se é que se combinam). É difícil pensar que elementos provenientes de culturas distintas - porque é disso que se trata - se encontram: não gosto tanto da noção de "encontro de culturas", porque esses supostos encontros normalmente são choques. Prefiro falar de "choques de culturas", em que, geralmente, é a cultura dominante que impõe seus valores.

Volto aqui ao tema que estudei em Le retour des ancêtres para especificar o que entendo por sincretismo pagão-cristão ou aculturação. É um caso de 
aculturação entre a cultura ocidental e a cultura andina, nesse caso. Mas o que acontece é que a cultura dominada andina integra elementos da cultura dominante, embora submetendo esses elementos à sua própria forma de pensamento que é, no caso andino - esquematizando muito -, um tipo de classificação dualista (com as categorias que citei antes, acima-abaixo, esquerda-direita etc.). Porque no sistema que chamo "pagão-cristão" dos Urus-Chipaya e dos Aymaras, significa que as entidades sagradas entram no sistema de classificação indígena. E o que acontece é que nesse sistema de classificação dualista andino, pagão-cristão, logicamente, os santos estão acima, no céu, a Pachamama está abaixo, a Pachamama feminina está do lado esquerdo, os santos do lado direito, os Mallkus estão abaixo, mas à direita etc. Os elementos ocidentais estão submetidos à lógica desse pensamento andino: eu diria que há uma "andinização" dos elementos ocidentais. É uma sociedade dominada que continua com seu tipo de pensamento e que integra elementos de fora. De tal maneira que, sem querer ofender a fé cristã, ao menos nos anos I970 quando eu fazia trabalho de campo, os Chipayas estavam bem divididos entre os tradicionalistas (que seguiam os ritos pagãos), os que haviam se convertido ao pentecostalismo - e que haviam recusado, claro, toda idolatria e todo paganismo - e os católicos que faziam uma "contrarreforma" em relação aos pentecostalistas, recusando também o que haviam tolerado durante cinco séculos.

E para responder a sua pergunta a propósito da aculturação da sociedade dominada - estou pensando na época colonial, na sociedade criolla -, no Brasil não há como insistir mais sobre a integração de elementos indígenas ou africanos: vocês sabem melhor que eu sobre esse tipo de integração cultural. Em outro contexto, tenho de mencionar o excelente trabalho da minha colega e amiga Solange Alberro (I992), que estudou esse tipo de aculturação na sociedade criolla do México, no que diz respeito à culinária, à medicina, à cultura, de modo geral.

A.D. Ao ouvi-lo agora e ao pensar no que é dito de modo explícito em A fé na lembrança, o seu trabalho de pesquisa guarda muitas identidades com os trabalhos de micro-história. Além de uma identidade de problemática, há também uma identidade de procedimentos. Se tomarmos o diagnóstico feito hoje sobre o trabalho de Carlo Ginzburg, que partiria de uma micro-história para chegar numa macroantropologia, talvez se possa reconhecer um modelo semelhante, na sua obra, mas com pontos de saída e de chegada diversos: o seu trabalho parte de uma etnografia - num nível que se situa, para dizer como Jacques Revel, "ao rés do chão" - para chegar numa história total. Nesse sentido, sobretudo, o livro Mémoires marranes compõe-se com a coleta de uma série de trajetórias, de pequenas histórias, com a função de trazer à tona, através de uma etnografia muito localizada, uma história de longa duração que - na totalidade dos livros da trilogia - remonta aos tempos inquisitoriais. Qual seria, então, o 
valor dessas abordagens "micro" e "macro", nas perspectivas histórica e antropológica assumidas na sua obra?

N.W. Você mencionou a obra de Carlo Ginzburg. Lembro que o estimo muito e o leio com o maior interesse. Realmente, é um autor com quem compartilho muitas perspectivas. Talvez por falta de competência minha, não sei se estou totalmente convencido pelo imenso quadro da última parte de Os andarilhos do bem (I988), mas estou totalmente de acordo com um artigo de Ginzburg que se chama, exatamente, O inquisidor como antropólogo (I99I). Compartilho do que afirma nesse texto porque, precisamente, os interrogatórios dos arquivos inquisitoriais são um trabalho de campo. O inquisidor se comporta - não com as mesmas intenções, com isso estamos todos de acordo - como o antropólogo que faz perguntas e se informa. Isso é etnografia ou micro-história. E a micro-história é interessante na medida em que tal caso vem complementar outro caso.

Para mim, história e antropologia se distinguem apenas por suas fontes: dito de modo simples, o trabalho de campo por um lado, os arquivos do outro. Concordo com sua análise: começo com algo que está efetivamente no nível do indivíduo, seja como etnógrafo ou como historiador, recolhendo relatos de vida, como fiz em Mémoires marranes. Não pretendi fazer uma combinação completa, equilibrada, como tratei de fazer em Le retour des ancêtres. Por razões pessoais, eu não tinha disponibilidade para dedicar anos ao trabalho de campo, como no trabalho com os Urus-Chipaya, e tampouco para fazer uma história total à maneira dos Annales. Em Le retour des ancêtres, as curvas demográficas, as curvas de preços, como disse, serviram para estabelecer que a sedentarização dos Urus-Chipaya ocorreu na fase conflituosa de população abundante e terra rara. No caso de Mémoires marranes, não havia razão para passar por curvas e outros métodos de história demográfica, mas acredito que se pode dizer que há algo totalizador no tema, que é precisamente buscar esses traços do passado no presente. Não é o mesmo tipo de totalização, mas é uma maneira de sair do indivíduo, da memória individual para chegar - como dizia Halbwachs - à memória coletiva. Mas com a memória coletiva chegamos a outra totalização. E como chegamos a essa memória coletiva? Passando pelo "micro". Um exemplo disso está numa sugestão de estudo que faço aos estudantes que estão em busca de temas para uma pesquisa de doutorado, seguindo a inspiração de Lévi-Strauss, sobre os sistemas de matrimônio dos cristãos-novos. A memória genealógica dos judeus marranos que vivem hoje no Nordeste do Brasil não apenas é mais profunda que a dos mexicanos: o que eles mantiveram e, sobretudo, que não encontrei em Venta Prieta, no México, foi o sistema de matrimônio endógamo. A sobrevivência desse sistema é um fator de transmissão da memória e da identidade.

Não pretendi, como digo na introdução de Mémoires marranes, fazer mais que uma história oral - com toda a sua legitimidade, através da coleta de relatos de vida. Com um trabalho desse tipo, eu havia tido uma experiên- 
cia análoga, ao lado da minha colega Lucette Valensi, quando publicamos Mémoires juives (1986). Nos anos I970, houve uma "onda" de autobiografias de autores que eram crianças durante os anos da Guerra. Eram autobiografias particularmente de autores judeus que haviam imigrado para França, seja da Europa centro-oriental, seja dos países mediterrâneos. Então, minha colega se encarregou de coletar uma parte dessas histórias, ou seja, as dos imigrantes sefarditas, e eu me encarreguei de outra, as dos imigrantes da Europa centro-oriental, na França. O que aconteceu, ao longo da coleta e da publicação dessas "memórias", foi que temas recorrentes apareceram. E não é extraordinário que os temas se repetissem: a nostalgia do bairro onde eles haviam vivido (na Argélia, no Marrocos ou na Polônia), a nostalgia da escola, as peripécias da migração, da adaptação nos anos de Guerra, entre tantos outros. A síntese de todas essas memórias individuais produz, assim, uma memória coletiva. Nas entrevistas que fiz no Brasil, em São Paulo, no Rio, em Recife, em Natal ou no sertão havia muitos temas recorrentes como esses. O mais recorrente deles era o fato de os entrevistados pertencerem a famílias cristãs, mas famílias com algo particular, com costumes particulares. Que costumes são esses? Proibições de alimentação, de comer porco, ou costumes funerários particulares, como o de enterrar os mortos em terra limpa com a mortalha (algo bem difundido até os anos I980, em todo o sertão do Nordeste). E muitos cumprem o mesmo itinerário, por várias razões (de estudo, de trabalho, de saúde): migram para a cidade e se dão conta de que esses costumes familiares, que pensavam ser totalmente cristãos, não são recomendados pela Igreja. Então, tomam consciência de uma diferença e, em outro meio, começam a se perguntar, a investigar, a tratar de dar uma resposta a isso. E a resposta mais verossímil é que há algo de "judaico" nesses costumes. Em suma, um dia tomam consciência, de uma maneira por vezes repentina, de que há uma origem judaica de suas práticas. Essa revelação daquilo que já era sabido (“tomei consciência de algo que já sabia"), essa memória semiconsciente, é algo recorrente nessas histórias. E, depois, a maneira de reagir a essa tomada de consciência pode desencadear muitas escolhas, seja regressar ao judaísmo, seja continuar com os costumes familiares como eram ou, em muitos casos, até mesmo converter-se ao evangelismo. Em todo caso, esses itinerários são recorrências de uma memória coletiva. E passamos assim, para não perder o fio da meada, do "micro" ao "macro".

A.D. Ao cabo desses diversos itinerários de marranos que exerciam sua fé de modo secreto, interno, como efeito da conversão forçada a que foram submetidos desde o século XV, na Europa e em seguida na América, onde encontraram refúgio, surgem determinadas formas de tolerância, como se pode ler em Mémoires marranes. Essas formas de tolerância se aproximam de formas de pensamento cético, igualmente muito antigas, como as que podem ser lidas, por 
exemplo, em Michel de Montaigne. Nesse mesmo sentido, quando perguntado sobre a sua fé, a sua resposta costuma ser "eu sou spinozista"...

N.W. Sim, claro, e continuo spinozista...

A.D. Então, o que significa ser spinozista no século XXI?

N.W. Talvez signifique o que significava na época de Spinoza, que era o espírito mais subversivo do século XVII (junto com Isaac La Peyrère). Era o autor mais escandaloso do século XVII. Espero não ser tão escandaloso quanto Spinoza!

A.D. E por quê?

N.W. Por sua liberdade de espírito, por seu espírito de crítica do que era considerado como palavra sagrada, bíblica. Como fez Isaac La Peyrère, significa dizer, de maneira tranquila, que a Bíblia - com todo o respeito que devemos ter - tem de ser estudada como qualquer documento histórico, de maneira profana. Isso era subversivo no século XVII, mas tão racional que segue vivo no presente. Esse passado segue vivo no presente, esse espírito de distanciamento - que era também o de Montaigne -, de relativismo das culturas (mas não de relativismo dos valores, isso é diferente). Não sou filósofo, mas o que representa Spinoza na história intelectual é algo que me parece positivo, e é nesse sentido que posso responder que sou spinozista.

Entrevista concedida em I8/I0/20I I | Aprovada em Io/05/20I 2 
Nathan Wachtel é professor honorário do Collège de France, onde ocupou, entre I992 e 2005, a Cátedra de História e Antropologia das sociedades meso e sul-americanas. Sua primeira obra de grande repercussão foi A visão dos vencidos (1972). Como diretor de estudos na École des Hautes Études en Sciences Sociales, a partir de I976, dedicou-se ao Centre de Recherches sur les Mondes Américains (CERMA), de que é hoje, igualmente, membro honorário. É autor de Le retour des ancêtres (I990), La foi du souvenir. Labyrinthes marranes (200I); La logique des bûchers (2009); Mémoires marranes (20I I); e Entre Moïse et Jésus (2013).

Andrea Daher é professora de teoria e metodologia da História na Universidade Federal do Rio de Janeiro (UFRJ), onde coordena o Laboratório de Pesquisa em História das Práticas Letradas. Seus estudos estão voltados para práticas culturais das épocas moderna e contemporânea, em particular as práticas de representação letrada e as relações entre oralidade e cultura escrita. É autora dos livros O Brasil francês (2007) e A oralidade perdida (2012). É titular, de 2010 a 20I4, da Cátedra de Ciências Sociais Sérgio Buarque de Holanda, junto à Maison des Sciences de l'Homme e à Universidade de Paris IV-Sorbonne, na França. 


\section{NOTAS}

* Nathan Wachtel, Professor Honorário do Collège de France, esteve na Universidade Federal do Rio de Janeiro a convite do Programa de Pós-graduação em Sociologia e Antropologia e do Programa de Pós-Graduação em História Social, como titular da Cátedra Claude Bernard, em outubro de 20I I, quando foi realizada a entrevista. A transcrição e a tradução foram feitas por Diego Galeano e a edição final e apresentação pela entrevistadora, Andrea Daher. Os livros citados ao longo da entrevista são os seguintes: La vision des vaincus. Les indiens du Pérou devant la conquête espagnole (I530-I570) (I97I); Le retour des ancêtres. Les indiens Urus de Bolivie, XXe-XXVIe siècle. Essai d'histoire régressive (I 990); La foi du souvenir. Labyrinthes marranes (200I); La logique des bûchers (2009); Mémoires marranes (20I I). O entrevistado e a entrevistadora assinam a dedicatória desta entrevista. 


\section{REFERÊNCIAS BIBLIOGRÁFICAS}

Alberro, Solange. (1992). Les Espagnols dans le Mexique colonial. Histoire d'une acculturation. Paris: Armand Colin.

Bloch, Marc. (2002). Apologia da história. O ofício do historiador. Rio de Janeiro: Zahar.

Bloch, Marc. (I946). L'étrange défaite. Paris: Gallimard.

Bloch, Marc. (I93I). Les caractères originaux de l'histoire rurale française. Paris: Les Belles Lettres.

Ginzburg, Carlo. (I99I). O inquisidor como antropólogo: uma analogia e as suas implicações. In: A micro-história e outros ensaios. Rio de Janeiro: Bertrand, p. 203-2I4.

Ginzburg, Carlo. (I 988). Os andarilhos do bem. Feitiçaria e cultos agrários nos séculos XVI e XVII. São Paulo: Companhia das Letras.

Lévi-Strauss, Claude. (200I). Tristes trópicos. São Paulo: Companhia das Letras.

Nora, Pierre \& Le Goff, Jacques (orgs.). (1976). História: novos problemas. Rio de Janeiro: Francisco Alves.

Valensi, Lucette \& Wachtel, Nathan. Mémoires juives. Paris: Gallimard-Julliard, I 986.

Wachtel, Nathan. (20I I). Mémoires marranes. Paris: Seuil.

Wachtel, Nathan. (2009). La logique des bûchers. Paris: Seuil.

Wachtel, Nathan. (2009). A fé na lembrança. Labirintos marranos. São Paulo: Edusp.

Wachtel, Nathan. (200I). La foi du souvenir. Labyrinthes marranes. Paris: Seuil.

Wachtel, Nathan. (I990). Le retour des ancêtres. Les indiens Urus de Bolivie, XXe-XXVIe siècle. Essai d'histoire régressive. Paris: Gallimard.

Wachtel, Nathan. (I97 I). La vision des vaincus. Les indiens du Pérou devant la conquête espagnole, I530-I570. Paris: Gallimard. 


\section{NATHAN WACHTEL: HISTÓRIA E ANTROPOLOGIA DE UMA AMÉRICA “SUBTERRÂNEA"}

Resumo

Nesta entrevista que Nathan Wachtel concedeu a Andrea Daher na Universidade Federal do Rio de Janeiro (UFRJ), um percurso feito a partir de sua vasta obra faz vislumbrar uma experiência de trabalho única, cujo fundamento é a junção do relato dos vivos à letra dos mortos, entre antropologia e história, em que índios ou marranos são os agentes da história de uma América "subterrânea", soterrada nas conquistas do passado, porém viva em vestígios de memórias no presente.

\section{NATHAN WACHTEL: HISTORY AND ANTHROPOLOGY OF A "SUBTERRANEOUS" AMERICA}

Abstract

In this interview with Andrea Daher at Federal University of Rio de Janeiro (UFRJ), Nathan Wachtel made a journey from his vast work experience that allows us to envisage a single work, whose foundation is the joint of the accounts of the living to the letter of the dead, between anthropology and history, in which Indians or Marranos are the agents of the history of "subterranean" America, buried in the achievements of the past, but live in the present traces of memories.
Palavras-chave

Antropologia;

História;

Marranismo;

Índios americanos;

Memória.

Keywords

Anthropology;

History;

Marranism;

American Indians;

Memory. 